РОЗРОБЛЕННЯ ПІДХОДІВ ЩОДО ТРАНСФОРМАЦІЇ «КЛІПОВОГО» МИСЛЕННЯ МАЙБУТНІХ УЧИТЕЛІВ БІОЛОГІЇ СПОСОБАМИ ОРГАНІЗАЦІї НАВЧАЛЬНО-ДОСЛІДНИЦЬКОЇ ДІЯЛЬНОСТІ У ФАХОВІЙ ПІДГОТОВЦІ

\title{
DEVELOPMENT OF APPROACHES IN RELATION TO TRANSFORMATION OF THE "CLIP THINKING" OF FUTURE TEACHERS BIOLOGY BY THE METHODS OF ORGANIZATION THE EDUCATIONAL-RESEARCH ACTIVITY IN PROFESSIONAL PREPARATION
}

у статті висвітлено питання та шляхи розв'язання психолого-педагогічної проблеми «кліпового» мислення, яке домінує у значної кількості сучасних студентів, зокрема, у студентів-біологів. Спостерігається тенденція посилення цього явища в учнівському середовищі. У результаті, в студентів (учнів) змінюється стиль, способи отримання інформації, їі обробки та накопичення. Саме такі умови задають необхідність інноваційних змін фоахової підготовки молоді загалом. Аналіз психолого-педагогічної літератури дав змогу виокремити провідні риси «кліпового» мислення на основ рівня розробленості проблеми у різних дослідженнях. У результаті такого аналізу шляхом ранжування виокремлено сім основних рис «кліповості»: висока швидкість сприйняття та поверхнева обробка інформаціі (кількісне оперування), переваги візуальноі (образноі) інфрормації, алогічність, дефріцит уваги та концентрації, знижена потреба та здатність до творчості, втрата бажання пізнання нового, фррагментарність та мозаїчність картин світу. Автори основним шляхом транссоормації «кліпового» мислення вважають продуктивну діяльність студентів. Одним із видів такої діяльності виокремлено навчально-дослідницьку. Серед способів ії організації провідні автори вбачають активізацію процесу навчання із залученням проблемно-пошукових та дослідницьких підходів. До ефекттивних прийомів організації навчально-дослідницької діяльності студентів, як показала апробація в курсі «Цитологія», віднесено: фрормування алгоритму відповіді на порівняння та інші логічні операції; заповнення опорних таблиць зі змістовими прогалинами; різноманітні прийоми з підвищення мотивації до пізнання; знаходження в навчальних текстах змістових одиниць для складання їх планів; застосування креалізованих текстів; складання кластерів, виокремлення головного в тексті в межах навчального матеріалу.

Ключові слова: мозаїчне, «кліпове» мислення, майбутні вчителі біології, риси «кліповості», продуктивна діяльність, навчально- дослідницька діяльність, прийоми, форми та методи навчально-дослідницької діяльності.

The article covers the issues and ways of its solution concerning the psychological and pedagogical problem of "clip" thinking, which is dominated by a large number of modern students, in particular, biologists. There is a tendency to increase this phenomenon in the student environment. As a result, students (pupils) change the style, ways of receiving information, its processing and accumulation. It is conditions, that determine the need for innovative changes in the professional training of young people in general. Analysis of psychological and pedagogical literature allowed highlight the main features of "clip" thinking based on the level of development of the problem in various studies. As a result of this analysis, seven key features of "clip art" are distinguished by ranking: high speed of perception and surface processing of information (quantitative operation), advantages of visual (figurative) information, logic, lack of attention and concentration, reduced need and ability to creativity, loss of desire for knowledge new, fragmentary and mosaic of world paintings. The authors consider the productive activity of the students as the main way of transforming "clip" thinking. One of the types of such activity is the educational-research. Among the ways of its organization, the leading authors see the activation of the learning process with the involvement of problem-searching and research approaches. The effective methods of organizing the teaching and research activities of students as demonstrated by the approbation in the course "Cytology", include: the formation of an algorithm for the answer to comparisons and other logical operations; filling in the reference tables with the content gaps; various techniques for increasing motivation to cognition; finding in the textbooks of content units for drawing up their plans; application of cited texts; assembling clusters, separating the main in the text within the educational material.

Key words: mosaic, "clip" thinking, future teach ers of biology, features of "clip", productive activity, teaching and research activities, techniques, forms and methods of teaching and research activities.
Постановка проблеми. На сучасному етапі розвитку цивілізації спостерігається активна та всеохоплююча інформатизація всіх сорер життя. Значні обсяги інформації щогодини свідомо та несвідомо сприймаються нами як належне. Це безпосередньо змінює стиль, способи ії отримання, обробки та накопичення. У таких умовах, запобігаючи перевантаженню вищої нервової діяльності людини, сприйняття такої інформації стає фррагментарним або мозаїчним. Вказане, на думку психологів, спричиняє виникнення «кліпового» сприйняття як складника «кліпового» мислення [14; 31; 35]. Найвразливішою соціальною категорією стосовно такого типу мислення $€$ сучасні студенти, які фрормуються і розвиваються разом $з$ комп'ютерним прогресом. Тому їхні основні мисленнєві операції відрізняються від людей 3 лінійним сприйняттям та понятійним мисленням. У результаті спостерігаємо невідповідність основних прийомів подачі навчального матеріалу з боку 
викладачів та його сприйняття студентами. Виходячи 3 цього, науковці наголошують на нагальній потребі переходу до нової освітньої парадигми, діючим інструментом якої є інноваційні методи та форми фрахової підготовки, які враховують такий тип мислення [34]. Феномен «кліповості» ґрунтовно доведений для студентів технічних напрямів підготовки [22]. Підтвердженням френомена «кліпового» мислення у майбутніх учителів біології $\epsilon$ результати їх анкетування нами у Національному педагогічному університеті ім. М.П. Драгоманова (Київ), Херсонському державному університеті (Херсон), Національному педагогічному університеті ім. О. Довженка (Глухів) та Рівненському гуманітарному університеті (Рівне). У ньому взяли участь 350 студентів з 1-го по 5-ий курси, які виконали тест для діагностування «кліпового» мислення за М. Літвіновою [21, с. 144]. Результати вказаного дослідження містить таблиця 1.

Аналіз анкетування засвідчив: 1) серед майбутніх учителів біології присутня значна частка студентів (37,4\%), яким притаманне «кліпове» мислення; 2) на різних курсах відсоток «кліповиків» неоднаковий; 3) спостерігається зменшення кількості студентів-«кліповиків» від 1-го до 5-го курсу; 4) виявлення такого френомена викликало зацікавленість не тільки у викладачів цих курсів, а й студентів-респондентів. Останні підтвердили існування певних труднощів під час підготовки до занять та домінування короткочасного запам'ятовування навчального матеріалу як власного відчуття, що є причиною труднощів під час складання колоквіумів і виконання завдань продуктивної спрямованості. Виявлені тенденції перевірили стосовно різних ЗВО (див табл. 2).
Як свідчать дані цієї таблиці, тенденції посилення феномена «кліповості» у різних вишах суттєво не відрізняються. Отже, фрахова підготовка майбутніх учителів біології, як і студентів технічних та інших природничих спеціальностей, потребує суттєвого ресормування в контексті «кліповості» мислення. Одним зі шляхів розв'язання вказаної проблеми $€$ підвищення рівня продуктивної діяльності студентів під час навчання. У психолого-педагогічній літературі [23; 36] € думка, що есеективним засобом такого підвищення $€$ цілеспрямований розвиток дослідницьких, зокрема навчально-дослідницьких умінь студентів. Такі уміння фрормуються у процесі організації відповідної діяльності [16].

Аналіз останніх досліджень. Поняття «кліпове» мислення в сучасній психолого-педагогічній та методичній літературі зустрічається все частіше і турбує науковців різних напрямів профресійної підготовки. Вперше цей термін (англ. clip - у перекл. відрізок) був використаний англійським фрутурологом Е. Тоффрлером. У разі характеристики сучасної культури отримання будь-якої інформації він наголошує на ії фррагментарності та різнорідності. Саме ці особливості подачі матеріалу, на думку фрахівця, фрормують фррагментарні та поверхневі знання [35]. Пізніше інший науковець, Ф. Гіренок, розширює межі цього поняття. Він вказує, що «кліп - це та частина, яка не має нічого спільного із загальним» [10, с. 16]. Вчений вбачає проблему в тому, що сучасні студенти за рахунок таких особливостей сприйняття та засвоєння інфрормації надалі оперують фріксованими «кліпами», які не дають змогу логічно мислити та вибудовувати причинно-наслідкові зв'язки

Таблиця 1

Результати анкетування з визначення «кліповості»

\begin{tabular}{|c|c|c|c|c|c|c|}
\hline Курс навчання & Усього & $\mathbf{1}$ курс & $\mathbf{2}$ курс & $\mathbf{3}$ курс & $\mathbf{4}$ курс & $\mathbf{5}$ курс \\
\hline Кількість анкетованих студентів & 350 & 66 & 88 & 89 & 88 & 62 \\
\hline Частка студентів 3 & 147 & 30 & 34 & 34 & 29 & 20 \\
\cline { 2 - 8 } \\
«кліповим» мисленням & $37,4 \%$ & $45,6 \%$ & $38,6 \%$ & $38,2 \%$ & $33 \%$ & $32 \%$ \\
\hline
\end{tabular}

Відсоток «кліповості» декількох університетів

Таблиця 2

\begin{tabular}{|c|c|c|c|c|c|}
\hline \multirow{6}{*}{ 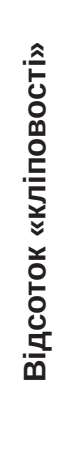 } & $\stackrel{0}{\grave{x}}$ & $\begin{array}{l}\text { НПУ ім. } \\
\text { м.П. Драгоманова } \\
\text { (Київ) }\end{array}$ & $\begin{array}{c}\text { Рівненський } \\
\text { державний } \\
\text { університет (Рівне) }\end{array}$ & $\begin{array}{c}\text { Національний } \\
\text { педагогічний університет } \\
\text { ім. О. Довженка (Глухів) }\end{array}$ & $\begin{array}{c}\text { Херсонський } \\
\text { державний } \\
\text { університет } \\
\text { (Херсон) }\end{array}$ \\
\hline & 1 & 43,75 & 44,4 & 44 & 35 \\
\hline & 2 & 37,5 & 40 & 33,3 & 40,5 \\
\hline & 3 & 35,7 & 35,3 & 30,4 & 45,7 \\
\hline & 4 & 38,4 & 31,8 & 30 & 30,3 \\
\hline & 5 & 35 & 27,3 & 29,4 & 25 \\
\hline
\end{tabular}


між явищами, процесами та подіями. Підтримуючи ідеї попередніх авторів, А. Ісаєва і С. Малахова називають першопричину цього френомена. Вона полягає у «кліповому» сприйнятті, яке в майбутньому порушує процес орормування контексту. Науковці висувають гіпотезу: «кліпове» сприйняття блокує враження та відношення, які $€$ необхідними атрибутами зрілої думки в процесі синтезу цілісного інтелектуального продукту [14] Інша група фрахівців з психології розвиває думку щодо особливостей інтелектуального та особистісного розвитку сучасних студентів, зокрема, в контексті «кліпових» форм сприйняття та переробки інфрормації. Їхні погляди одностайні в тому, що залежно від ступеня «кліповості» йдеться про «кліпове» сприйняття - «кліпове» мислення «кліпову» культуру - «кліпову» свідомість. Таке послідовне впровадження «кліповості» під час фрахової підготовки порушує процес фрормування фундаментальних знань, що є неприпустимим у профресійному становленні [1; 31; 36]. Вказане теоретичне підґрунтя та практичний досвід, що містять праці психологів, задали темп щодо розв'язання нагальної потреби інноваційного підходу в навчанні. Провідним серед розвитку напрямів такого підходу щодо когнітивної сфери студентів-«кліповиків» $\epsilon$ фрормування навичок аналізу і класифрікації інфрормаційного потоку [2; 7; 8; 13; 29]. У науково-педагогічній літературі $€$ низка праць, яка присвячена особливостям упровадження інноваційних фрорм, методів і прийомів, що безпосередньо спрямовані на риси «кліповості» студентів, зокрема, під час вивчення математики та фрізики в технічних та педагогічних 3 ВО $[4 ; 5 ; 25 ; 34]$. Це питання також розробляється для таких напрямів підготовки, як менеджмент соціокультурної діяльності [27], фрілології [11] і комп'ютерної інженерії [23].

Виділення не вирішених раніше частин загальної проблеми. Стосовно підготовки фрахівців-природничників ґрунтовні наукові напрацювання, в яких висвітлені особливості підготовки студентів-кліповиків», має лише методика навчання фрізики [22; 26]. В інших сучасних природничих методиках навчання ця проблема розроблена не досить. Проте мозаїчність мислення - серйозна перешкода у профресійній підготовці фрахівців у галузі природничих наук.

Тому метою дослідження стало виокремлення провідних рис «кліпового» мислення і підходів до організації навчально-дослідницької діяльності у підготовці майбутніх учителів біології під час навчання з урахуванням їхнього «кліпового» мислення.

Виклад основного матеріалу. Поняття «кліпове мислення» має полісемію визначення. В межах нашого дослідження під цією десініцією розуміємо процес відображення багатьох різно- манітних властивостей об'єктів без урахування зв'язків між ними. Воно характеризується фррагментарністю інфрормаційного потоку, алогічністю, повною різнорідністю інфрормації, що потрапляє з високою швидкістю переключення між її фррагментами та відсутністю цілісної картини сприйняття навколишнього світу [31]. Таким чином, Т. Семеновських, визначивши поняття «кліпове мислення», дорівнює його до когнітивного стилю. Т. Чиркова [36] висвітлює дещо інше бачення «кліпових» фрорм сприйняття та обробки інформації в когнітивній сорері сучасної молоді. Досліджуючи проблеми професійної підготовки бакалаврів психології, вона проводить паралель між «кліповим» та наочно-образним мисленням. На іiї думку, ці типи подібні за особливостями сприйняття навчального матеріалу у вигляді образів. Тому першою відмінною властивістю «кліпових» фрорм, за Т. Чирковою, є їх образність. Цей фрахівець у складі «кліповості» також називає підвищений емоційний складник у мотиваційно-регуляторних механізмах, що безпосередньо блокує потребу до пізнання нового. Однією з позитивних властивостей вказаного типу мислення Т. Чиркова виокремлює особливості фрормально-динамічних індивідуальних особливостей (швидкісні, ергічні та варіативні), що значно спростовують сприйняття та обробку значних обсягів сучасного інформаційного потоку [36]. У ґрунтовній праці М. Літвінової [22] з проблеми адаптивного навчання фрізики наведено більше, ніж десять ознак «кліповості».

Проведене дослідження - один зі шляхів розв'язання вказаної проблеми щодо підготовки майбутніх учителів біології. Першим його етапом стало виокремлення провідних рис «кліповості» мислення студентів на основі аналізу відповідної психологічної та науково-методичної літератури. Результати такого аналізу містить таблиця 3. Він дав змогу виокремити 24 риси «кліповості». Далі провели ранжування таких рис, що дало змогу виокремити 7 основних (у табл. 3 виділено курсивом). Вони найчастіше зустрічаються в працях фрахівців і тому їх можна вважати провідними властивостями френомена, що розглядається. Саме вони і стали об'єктом трансфрормації в межах фрундаментальних біологічних дисциплін, зокрема курсу «Цитологія», 3 метою зниження ступеня «кліповості» мислення студентів і підвищення результативності їхньої фрахової підготовки. Серед них - зниження рівня основних логічних операцій (аналізу, синтезу, порівняння, узагальнення та класифрікації); переваги візуальної (образної) інфрормації; висока швидкість сприйняття та поверхнева обробка інфрормації; десріцит уваги та її концентрації; фррагментарність та мозаїчність картин світу; втрата бажання до пізнання; знижена потреба та здатність до продуктивної діяльності. 
Провідні риси кліпового мислення студентів

Таблиця 3

\begin{tabular}{|c|c|c|c|c|c|c|c|c|c|c|c|c|c|c|c|c|}
\hline \multirow[b]{2}{*}{ № } & \multirow[b]{2}{*}{ Риси кліпового мислення } & \multicolumn{15}{|c|}{ Автори } \\
\hline & & 尺्్త & ্ָ] & ్ㅡㄴ & N & 운 & $\underset{\mathbb{U}}{\text { 足 }}$ & 그 & 吕 & N & : & 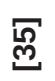 & ' & $\stackrel{\text { g }}{\mathrm{g}}$ & ্ָ] & $\stackrel{m}{\mathrm{~m}}$ \\
\hline 1 & $\begin{array}{c}\text { Непослідовне та нетекстове } \\
\text { сприйняття }\end{array}$ & + & & & & & & & & & + & & + & & & \\
\hline 2 & Безсвідоме засвоєння & + & & & & & & & & & & & & & & \\
\hline 3 & $\begin{array}{c}\text { Домінування короткочасного } \\
\text { запам'ятовування }\end{array}$ & + & & & & & & & & & + & & & & & \\
\hline 4 & $\begin{array}{c}\text { Вміння швидко переключатись } \\
\text { на нову задачу (подразник) }\end{array}$ & + & & & & & & + & & & & & & & & \\
\hline 5 & Багатозадачність & + & & + & & & & + & & + & & & & & & \\
\hline 6 & $\begin{array}{c}\text { Висока швидкість } \\
\text { сприйняття та поверхнева } \\
\text { обробка інфрормації (кількісне } \\
\text { оперування) }\end{array}$ & + & & & & & & + & & + & + & + & & + & + & \\
\hline 7 & $\begin{array}{c}\text { Підвищений емоційний стан } \\
\text { (гіперактивність) }\end{array}$ & + & + & & + & & + & & & & & + & & & & \\
\hline 8 & $\begin{array}{c}\text { Переваги візуальної (образної) } \\
\text { інфрормації }\end{array}$ & + & & & & & & + & + & & + & + & + & + & & \\
\hline 9 & $\begin{array}{c}\text { Знижена здатність до } \\
\text { основних логічних операцій } \\
\text { (аналіз, синтез, порівняння, } \\
\text { узагальнення та класифрікації) }\end{array}$ & & & + & + & + & + & + & + & + & + & & + & + & + & + \\
\hline 10 & Алогічність & & + & + & + & & & & & & + & + & & + & & \\
\hline 11 & $\begin{array}{l}\text { Оперування змістом } \\
\text { фріксованої довжини }\end{array}$ & + & + & & + & & & + & & & + & & + & & & \\
\hline 12 & $\begin{array}{c}\text { Конкретність та дискретність } \\
\text { мислення }\end{array}$ & & + & & & & & + & & & & & & & & \\
\hline 13 & Лабільність & & + & & & & & & & & & & & & & \\
\hline 14 & $\begin{array}{l}\text { Дефріцит уваги } \\
\text { та концентрації }\end{array}$ & & & & + & + & & + & & + & & & + & & + & \\
\hline 15 & $\begin{array}{c}\text { Знижена потреба та } \\
\text { здатність до творчості }\end{array}$ & & & & + & + & & & & & & & & & & \\
\hline 16 & $\begin{array}{l}\text { Втрата бажання } \\
\text { пізнання нового }\end{array}$ & & & & + & & & + & & & & + & & & & \\
\hline 17 & $\begin{array}{c}\text { Фрагментарність } \\
\text { та мозаїчність картин світу }\end{array}$ & + & + & & & & + & & & & & & & & & \\
\hline 18 & $\begin{array}{c}\text { Використання вторинної } \\
\text { інфрормації на рівні її } \\
\text { переробки та комбінування }\end{array}$ & + & & & + & & & & & & & & & & & \\
\hline 19 & $\begin{array}{l}\text { Неструктурованість } \\
\text { у бажаннях та вчинках }\end{array}$ & & & & + & & & & & & & + & & & & \\
\hline 20 & $\begin{array}{c}\text { Оперування тільки змістом } \\
\text { фріксованої довжини }\end{array}$ & + & & & + & & & + & & & + & & + & & & \\
\hline 21 & $\begin{array}{c}\text { Сприйняття інформації через } \\
\text { короткі, яскраві символи }\end{array}$ & & & & & & & + & + & & & & & & & \\
\hline 22 & $\begin{array}{c}\text { Диспропорція між формаль- } \\
\text { ним та реальним рівнем знань }\end{array}$ & & & & + & & & & & & & & & & & \\
\hline 23 & $\begin{array}{c}\text { Відсутність потреби до } \\
\text { запам'ятовування, звички до } \\
\text { легкодоступності інорормації }\end{array}$ & + & & & & & & & & & & & & & & \\
\hline 24 & $\begin{array}{c}\text { Відсутність враження } \\
\text { і ставлення }\end{array}$ & & & & & & & & & & & & & & & + \\
\hline
\end{tabular}


Наступним етапом дослідження став аналіз відповідних літературних першоджерел з метою ефрективного винаходу методичних засобів впливу на ці провідні риси «кліповості» студентів. Було 3'ясовано, що в науково-методичній літературі $€$ праці, які містять підходи, котрі спрямовані на організацію продуктивної діяльності студентів у контексті їх «кліповості». Таким прикладом $€$ дисертаційне дослідження М. Літвінової [22], яка пропонує різноманітні методи, фрорми і прийоми організації продуктивної діяльності студентів під час навчання фрізики. Серед них вона виокремлює візуалізацію навчальної інформації, проектноігрові прийоми 3 використанням метафоричноасоціативних карт. Окрім цього, в основі прийомів організації навчальної діяльності фрахівець вбачає часту зміну видів діяльності, джерел інформації, створення центрального образу явища або поняття, що вивчається. Вищевказаний науковець наголошує на необхідності створення освітнього продукту, нового для тих, хто навчається [22]. Підтримуючи попереднього фахівця, В. Лозицький розглядає продуктивну діяльність студентів як провідний шлях до подолання «кліповості» сучасних студентів -інфрорматиків. Серед способів її організації він називає активізацію процесу навчання із залученням проблемно-пошукових, дослідницьких підходів у навчанні; науковість змісту навчання; забезпечення можливості побудови всіх видів діяльності на науково обґрунтованих принципах [23]. Така позиція авторів не випадкова. У педагогічній теорії і на практиці процес навчання розглядають насамперед як діяльність. В. Беспалько виокремив три її види: репродуктивну, продуктивну і творчу. Відмінна особливість людини (ії свідомості і мислення) полягає в тому, що вона може виконувати як репродуктивну, так і продуктивну діяльність за нестачі інорормації, отримуючи її з різних джерел. На думку цього науковця, репродуктивна діяльність - початковий етап освоєння діяльності, яка має на меті засвоєння готових знань та способів дії в певних ситуаціях (точне відтворення уже відомого). Продуктивна діяльність - вид діяльності, що призводить до генерування нових знань і способів діяльності, які особистість не отримала в готовому вигляді (переробка відомого і створення суб'єктивно нового). Творча діяльність - це вищий рівень розвитку людської здатності до застосування раніше засвоєної інформації шляхом їі перетворення, вдосконалення і створення ії об'єктивно нового продукту (знань, об'єктів тощо) [6]. 3. Калмикова пов'язує продуктивну діяльність 3 продуктивним мисленням і вказує на відмінність його від репродуктивного. Вона вважає провідною відмінністю цих різновидів мислення у ступені «новизни отриманого в процесі мисленнєвої діяльності продукту стосовно отриманих знань» [15, с. 194-198]. Тому доцільно буде виокремити десрініцію «навчальнодослідницька діяльність» крізь призму продуктивності навчання як основного прийому пластичності «кліпового мислення» в бік його логічності. Продуктивна діяльність у методиці навчання має відображення у певних різновидах навчальної діяльності [18; 30]. Аналіз науково-методичних джерел, що проведений нами раніше [16], свідчить про те, що навчально-дослідницьку діяльність (НДД) можна розглядати у складі таких різновидів. У нашій попередній праці [17] НДД визначена як різновид продуктивної діяльності студентів, що спрямована на одержання професійних знань і фрормування навчальних умінь інноваційними методами навчання, її результатом є отримання суб'єктивно нових знань.

Виходячи 3 вищевказаного, наступним етапом дослідження став аналіз та добір методів, форм і прийомів організації навчально-дослідницької діяльності студентів, які б сприяли певній трансфрормації рис їх «кліповості». Таблиця 4 містить провідні риси «кліповості» та відповідно до їх специоріки сприйняття, обробки та оперування інфрормації (знань), методи, фрорми та прийоми НДД. Останні наведені у відповідних літературних першоджерелах. Отже, фрормування навчальнодослідницьких умінь (НДУ) студентів можна розглядати як один із засобів трансорормації «кліпового» мислення у бік логічного. Підтвердження сорормульованого припущення знаходимо у працях науковців [23; 35].

Подальший аналіз психолого-педагогічної літератури з проблеми інноваційних підходів у підготовці фрахівців у контексті врахування і трансформації «кліповості» студентів дав змогу відібрати ефективні методи і форми організації НДД. Вищевказане і стало останнім етапом нашого дослідження. Таблиця 4 містить результати цієї праці. Такий добір здійснений на основі рівня розробленості дидактичного супроводу у літературних першоджерелах щодо врахування і транссрормації рис «кліповості».

Стосовно добору методичних прийомів для реалізації відповідних методів і фрорм під час підготовки вчителів біології в навчанні цитології апробовані такі (в табл. 4 виділені курсивом): фрормування алгоритму відповіді на порівняння та інші логічні операції; заповнення опорних таблиць зі змістовими прогалинами; різноманітні прийоми щодо підвищення мотивації; знаходження в тексті змістових одиниць для складання планів навчальних текстів; застосування креалізованих текстів; складання кластерів, виокремлення головного в тексті.

Висновки. Проведене дослідження засвідчило, що:

- майбутнім учителям біології, як і студентам інших напрямів підготовки, притаманна «кліповість» мислення; 
- спостерігається тенденція посилення цього явища в студентському середовищі;

- провідними властивостями «кліпового» мислення $€$ зниження рівня основних логічних операцій (аналіз, синтез, порівняння, узагальнення та класифікації); перевага візуальної (образної) інформації; висока швидкість сприйняття та поверхнева обробка інформації; дефріцит уваги та ії концентрації; оррагментарність та мозаїчність картин світу; втрата бажання до пізнання; знижена потреба та здатність до продуктивної діяльності. Більшість 3 них можна трансорормувати за умови особливостей організації навчання;
- нарощування тенденції домінування «кліпового» над понятійним мисленням задає новий стиль у навчальній діяльності, зокрема, в процесі отримання, обробки, збереження та реалізації інорормації студентом;

- одним 3 провідних напрямів фрахової підготовки в контексті «кліповості» мислення студентів, що забезпечує продуктивну діяльність студентів, $€$ організація їх навчально-дослідницької діяльності;

- впровадження такої діяльності - ефективний засіб трансорормації «кліпового» мислення в бік його логічності і, відповідно, підвищення результативності навчання;

Підходи щодо організації навчально-дослідницької діяльності

\begin{tabular}{|c|c|c|c|}
\hline № & Риси кліповості & Методи, форми організації НДД & $\begin{array}{c}\text { Приклади методичних прийомів } \\
\text { організації НДД }\end{array}$ \\
\hline 1 & \begin{tabular}{|l} 
Знижена здатність \\
до основних логічних \\
операцій (аналіз, синтез, \\
порівняння, узагальнення та \\
класифікації). Алогічність. \\
\end{tabular} & $\begin{array}{l}\text { Інноваційна лекція, яка містить } \\
\text { систему інтелектуальних завдань: } \\
\text { а) комп'ютерні симуляції; } \\
\text { б) ділові та рольові ігри; } \\
\text { в) розбір конкретних ситуацій [19]; }\end{array}$ & $\begin{array}{l}\text { 1. «Метод парадоксів» [4]; } \\
\text { 2. Формування алгоритму } \\
\text { відповіді на порівняння } \\
\text { та інші логічні операції }\end{array}$ \\
\hline 2 & $\begin{array}{l}\text { Переваги візуальної } \\
\text { (образної) інфрормації }\end{array}$ & $\begin{array}{l}\text { 1) Лекція-візуалізація [13]; } \\
\text { 2) Фрейми, блоки-схеми, } \\
\text { матрично-таблична опора [25]; } \\
\text { 3) Застосування креалізованих } \\
\text { текстів [11; 26]; } \\
\text { 4) Інфоромаційні схеми [4]; }\end{array}$ & $\begin{array}{l}\text { 1) Яскраве ілюстрування з } \\
\text { використанням візуальних, } \\
\text { аудіальних та кінеститичних ознак; } \\
\text { 2) закріплення (якоріння) ознак, } \\
\text { пов'язаних з певними явищами; } \\
\text { 3) створення коротких слайд- } \\
\text { презентацій, кіносррагментів, } \\
\text { візуальних рядів; } \\
\text { 4) створення блок-схем } \\
\text { та інших графрічних образів [22]; }\end{array}$ \\
\hline 3 & $\begin{array}{l}\text { Висока швидкість } \\
\text { сприйняття та поверхнева } \\
\text { обробка інфрормації }\end{array}$ & $\begin{array}{l}\text { Робота з великими обсягами } \\
\text { інфрормації у самостійному пошуку } \\
\text { і самостійні висновки [20]; }\end{array}$ & $\begin{array}{l}\text { Заповнення опорної таблиці } \\
\text { зі змістовими прогалинами [4]; }\end{array}$ \\
\hline 4 & $\begin{array}{l}\text { Десріцит уваги та } \\
\text { концентрації }\end{array}$ & $\begin{array}{l}\text { Виділення смислових одиниць } \\
\text { [33, с. 132]; }\end{array}$ & $\begin{array}{l}\text { Знаходження в тексті змістових } \\
\text { одиниць; складання планів навчаль- } \\
\text { них текстів }\end{array}$ \\
\hline 5 & $\begin{array}{l}\text { Фрагментарність } \\
\text { та мозаїчність картин світу }\end{array}$ & $\begin{array}{l}\text { 1) Блочне вивчення матеріалу } \\
\text { (модулі, страти); } \\
\text { 2) Складання кластерів } \\
\text { (простих та складних) [13]; }\end{array}$ & $\begin{array}{l}\text { 1) Швидкі відповіді на серію питань, } \\
\text { що мають різну конструкцію; } \\
\text { 2) заповнення фрактичних, } \\
\text { смислових, логічних прогалин у } \\
\text { вивченому понятті, явищі з різних } \\
\text { джерел інформації; } \\
\text { 3) виділення найбільш важливої } \\
\text { інорормації (понять, прикладів) } \\
\text { у тексті [22]; }\end{array}$ \\
\hline 6 & Втрата бажання до пізнання & $\begin{array}{l}\text { 1) Використання вузько-тематичних } \\
\text { фрільмів (відеороликів, з наочними } \\
\text { прикладами, експериментами) [31]; } \\
\text { 2) метод проектів }\end{array}$ & $\begin{array}{l}\text { 1) Створення творчого продукту [22]; } \\
\text { 2) різноманітні прийоми } \\
\text { щодо підвищення мотивації з } \\
\text { використанням різнобічної цікавої } \\
\text { інфрормації з навчальної дисципліни }\end{array}$ \\
\hline 7 & $\begin{array}{l}\text { Знижена потреба та } \\
\text { здатність до продуктивної } \\
\text { діяльності }\end{array}$ & $\begin{array}{l}\text { 1) Кейс-метод (спільна творча } \\
\text { діяльність студентів) [13]; } \\
\text { 2) Пошуково-дослідницький метод; } \\
\text { 3) Метод «мозкового штурму»; } \\
\text { 4) Метод випадковостей, помилок та } \\
\text { асоціацій [9, с. 46]; } \\
\text { 5) Використання дослідницьких } \\
\text { завдань з використанням оптима- } \\
\text { льних алгоритмів [23]. }\end{array}$ & $\begin{array}{l}\text { 1) Проблемно-пошукові завдання } \\
\text { в межах певної дисципліни з } \\
\text { виокремленням основних ї̈ етапів: } \\
\text { постановка проблеми, висунення } \\
\text { гіпотез, аналіз проблемної ситуації } \\
\text { та нестандартне ії розв'язання [3]; } \\
\text { 2) дослідницькі проби [36]. }\end{array}$ \\
\hline
\end{tabular}


- до еорективних прийомів організації навчально-дослідницької діяльності студентів, як показала апробація в курсі «Цитологія», можна віднести фрормування алгоритму відповіді на порівняння та інші логічні операції; заповнення опорних таблиць зі змістовими прогалинами; різноманітні прийоми щодо підвищення мотивації; знаходження в тексті змістових одиниць для складання планів навчальних текстів; застосування креалізованих текстів; складання кластерів, виокремлення головного в навчальному матеріалі.

Подальшим завданням $€$ добір та впровадження методичних прийомів для реалізації методів і фрорм у межах інших фрундаментальних біологічних дисциплін (генетика, екологія, еволюційне вчення) під час фрахової підготовки майбутніх учителів біології з урахуванням їхнього кліпового типу мислення.

\section{БІБЛІОГРАФІЧНИЙ СПИСОК:}

1. Азаренок Н.В. Клиповое сознание и его влияние на психологию человека в современном мире. Психология человека в современном мире. 2009. С. $110-112$.

2. Аксенов Л.Б. Влияние клипового мышления на образовательный процесс в вузе. Актуальные проблемы гуманитарных и естественных наук. 2014. № 10. C. 320-323.

3. Антонюк Л.В. Навчально-дослідницька діяльність як компонент професійного становлення студентів фрізико-математичного напряму підготовки. URL: http://ps.stateuniversity.ks.ua/file/issue_62/44.pdf (дата звернення: 10.05.2019).

4. Бабичева И.В., Болдовская Т.Е. Адаптация системы математической подготовки в вузе с учётом «клипового» мышления обучаемых. Наука о человеке: гуманитарные исследования. 2017. № 1(27). С. 126-132.

5. Бахтіна Г.П. Математика як «щеплення» проти «кліповості» інорормації та «колажу» сучасного мислення. Педагогічні науки. 2010. № 1 (188), січень. С. 144-155.

6. Беспалько В.П. Параметры и критерии диагностичной цели. Школьные технологии. 2006. № 1. С. 118-128.

7. Берулава Г.А., Берулава М.Н. Новая сетевая теория развития личности в инорормационном образовательном пространстве. Психологическая наука и образование. 2012. № 1. С. 5-17.

8. Бубич О.А., Гилевич Е.Г. Клиповое мышление и организация педагогического процесса в вузе. общественные науки: Народное образование. Педагогика. ЭБ БГУ. 2016. С. 65-71.

9. Буш Г.Я. Методологические основы научного управления изобретательством. Серия «Библиотека рационализатора». Рига : Издательство «Лиесма», 1974. $170 \mathrm{c}$.

10. Гиренок Ф.И. Клиповое сознание: клипы в науке, клипы в фрилософиии, клипы в политике, клипы в искусстве, клипы в образовании. Москва : Проспект, 2016. 256 с.
11. Гич Г.М. «Кліпове» мислення молоді: друг чи ворог навчання. Наукові праці. Серія: Педагогіка. чДУ ім. П. Могили. Миколаїв. 2016. Вип. 257. С. 38-42.

12. Докука С.В. Клиповое мышление как френомен информационного общества. Общественные науки и современность. 2013. № 2. С. 169-176.

13. Землинская Т.Е., Ферсман Н.Г. Методика вузовского обучения в контексте клипового мышления современного студента. Гуманитарные и общественные науки: научно-технические ведомости СПбГПУ. 2016. № 4 (255). С. 155-158.

14. Исаева А.Н., Малахова С.А. «Клиповое мышление»: психологические дефициты и альтернативы (пространственный фрокус). Мир психологии. 2015. № 4 (84). С. 177-191.

15. Калмыкова 3.И. Продуктивное мышление как основа обучаемости : монографрия. Москва : НИИ общ. и пед. психологии АПН СССР, 1981. 200 с.

16. Кістін Ю.О. До проблеми формування дослідницьких умінь майбутніх біологів. Педагогічні науки: реалії та перспективи : збірник наукових праць. Вип. 47. Київ. 2014. С. 99-109.

17. Кістін Ю.О. Розмежування понять «навчальнодослідна» та «науково-дослідна» діяльність студентів-біологів. «Науково-дослідна робота молодих учених: стан, проблеми і перспективи» : матеріали II Всеукраїнської науково-практичної інтернет-конореренції. 2013. Херсон. С. 93-102.

18. Коряковцева Н.Ф. Современная методика организации самостоятельной работы изучающих иностранный язык : пособие для учителей. Москва : АРКТИ, 2002. 176 с.

19. Красинская Л.Ф. Учимся учить по-новому, или О неиспользованных возможностях лекции. Высшее образование в России. 2011. № 2. С. 98-103.

20. Кузнецова Е.В., Резер Т.М. Клиповое мышление как фрактор изменения образовательных технологий в высшей школе. Акмеология профессионального образования : материалы 14-й международной научно-практической конференции. Екатеринбург. 2018. С. 367-370.

21. Літвінова М.Б. Досвід діагностування кліпового мислення. Педагогічні науки : збірник наукових праць. Випуск LXXVI. 2017. Т. 3. С. 140-158.

22. Літвінова М.Б. Методична система адаптивного навчання фрізики у закладах вищої технічної освіти : дис .... д-ра пед. наук : 13.00.02. Центральноукраїнський державний педагогічний університет ім. В. Винниченка. Кропивницький, 2018. 517 с.

23. Лозицкий В.Л. Феномен клипового мышления и информационно-коммуникационные технологии в высшем просресиональном образовании. Научные труды Республиканского института высшей школы. 2016. С. 375-379.

24. Неклюдова В.В. Развитие теоретического мышления как основа профессионального становления студента. Проблемы современного педагогического образования. Ялта. 2017. С. 294-301.

25. Нестерова Л.Ю., Напалков С.В. Развитие клипового мышления у студентов в системе высшего образования посредством опорных грасрсхем. Вестник Нижегородского университета им. Н.И. Лобачевского. Социальные науки. 2016. № 4 (44). С. 207-215. 
26. Паніна О.П. Система навчання фрізики і контролю та самоконтролю знань 3 фрізики курсантів морських ЗВО з використанням креолізованих текстів та інтелектуальних карт. Педагогічні науки: реалії та перспективи : зб. наук. праць. Київ. 2017. Вип. 59. С. 103-113.

27. Полевой С.А., Павлова В.В. Особенности обучения студентов с клиповым мышлением. Открытое образование : сборник научных трудов. T. 21. № 2. 2017. C. 56-67.

28. Поліщук К.О. Вплив споживання інфрормаційних технологій на людство. Грані: Філософрія. № 4 (120). 2015. С. 127-131.

29. Пронин В.В. Клиповое мышление студента в дистанционном обучении. Вестник Нижегородского университета им. Н.И. Лобачевского. 2014. № 2 (2). C. 468-471.

30. Пташенчук О.О. Формування дослідницької компетентності майбутніх учителів біології у процесі фрахової підготовки : дис. к. пед. наук : 13.00.04. Сумський державний педагогічний університет імені А.С. Макаренка. Суми, 2018. 347 с.
31. Семеновских Т.В. Феномен клипового мышления в образовательной вузовской среде. Науковедение. Эдукология и педагогика. 2014. № 5(24). С. 17-23.

32. Старицына О.А. Клиповое мышление vs образование. Кто виноват и что делать. Azimuth of scientific Research: Pedagogy and Psychology. 2018. T. 7. № 2(23). C. 270-274.

33. Талызина Н.Ф. Педагогическая психология : учебное пособие для студентов средних педагогических учебных заведений. Москва : Издательский центр «Академия», 1998. 288 с.

34. Тестов В.А. Переход к новой образовательной парадигме в условиях сетевого пространства. Bестник Нижегородского университета. Инновации в образовании. 2012. №4 (1). С. 50-56.

35. Тоффрлер Э. Шок будущего. Москва : АСТ, 2002. 557 c.

36. Чиркова Т.И. Проблема преодоления клипового сознания молодёжи в профессиональной подготовке психологов на уровне бакалавриата. Психологическая наука и образование. 2016. Т. 8. № 1. C. 45-61. 